\title{
Nurses' Application of Infection Control Measures related to Urinary Catheter Care
}

\author{
Mona Mohamed Mayhob, Lecturer \\ Adult Health Nursing, Faculty of Nursing, the British University in Egypt \\ Tahany El Senosuy, Professor \\ Medical Surgical Nursing, Faculty of Nursing, Ain Shams University
}

\begin{abstract}
Urinary catheter care is one of the most important practices performed by nurses. This practice should be done following related infection control measures in order to avoid urinary tract infection (UTI). Objective: Assess nurses' application of infection control measures related to urinary catheter care. Setting: The study was carried out at the National Institute of Kidney Diseases. Subjects: The study sample included all nurses working in the above settings. Their number amounted to 67. Tools: Four tools were used to collect the needed data. Nurses' socio-demographic data structured interview schedule, Nurses' knowledge self-administered questionnaire. Nurses' performance observation checklist and Nurses' attitude. Results: This study revealed that, $64 \%$ of the studied sample had satisfactory level of knowledge, while 59\% of them had satisfactory level of practices in relation to application of infection control measures for urinary catheter care. Conclusion: The application of infection control measures in caring for urinary catheter was affected significantly by nurses' knowledge and attitude. Recommendations: It is recommended that, all nurses working in different units and wards in the hospital should attend training courses in order to upgrade themselves and update their knowledge and improve their practice.
\end{abstract}

Keywords: Infection control; Measures; Urinary catheter care

\section{Introduction}

Urinary tract infection (UTI) accounts $50 \%$ among patients worldwide who are connected with urinary catheter ${ }^{(1)}$. Performing proper nursing care could help in preventing occurrence of urinary tract infections ${ }^{(2)}$. Urinary catheter is commonly inserted in the patient to assess urine output, facilitate urinary bladder drainage, and help while providing care for patients with unstable hemodynamic condition. Urinary catheter may remain inserted in the patient for few hours or days during hospitalization period. Worldwide, the patients who are connected with urinary catheter have a 3-7\% risk to acquire urinary tract infection ${ }^{(1-3)}$.

Urinary catheter care is an essential nursing practice. The nurse has the responsibility for applying all infection control measures while performing urinary catheter care to inhibit spreading of infection associated with urinary catheterization.
Therefore, when nurses neglect to apply the infection control measures while providing urinary catheter care; their patients will be liable to develop serious complications such as bacteriuria and funguria ${ }^{(4)}$.

Urinary tract infection associated with urinary catheter has significant clinical and economic consequences. It may be associated with excess mortality, even after controlling for underlying factors such as severity of illness and comorbidities; hospital-onset bloodstream infection resulting from a urinary source has a case fatality of $32.8 \%{ }^{(5,6)}$.

One of the most important roles of the nurse while performing urinary catheter care is to follow the basic infection control measures such as; wash hands before starting the procedure, wear gloves, and wash the catheter insertion site by using soap and water. While performing urinary catheter care for female patients washing must be done from the front toward the back 
to prevent contamination of the insertion site of the catheter with bacteria from the rectal area. In addition, the nurse should maintain the proper position of urinary catheter and drainage bag; it must be fixed below the level of the urinary bladder, to prevent ascending infection, promote and facilitate the drainage of urine and avoid stagnation of urine in the collection tube or moving back into the urinary bladder ${ }^{(5)}$.

Several researches revealed that proper urinary catheter care could help in prevention of UTI associated with urinary catheter; therefore, it is very crucial to assess and monitor the nurses' knowledge, attitude and practice regarding urinary catheter care, as well as application of infection control measures. Standard precautions must be applied while performing urinary catheter care are as follows; hand hygiene, use personal protective equipment (PPE) and management of waste. In addition, there are some specific precautions that should be taken into consideration while providing care such as; rapid drainage of large volumes of urine from the bladder may result in hypotension and/or hemorrhage. If the volume seems excessive, clamp the catheter. Release clamp after 20 minutes to allow more urine to drain. For post obstructive diuresis IV replacement of fluid and electrolytes may be required ${ }^{(7)}$.

\section{Significance of the study:}

Urinary tract infection is one of the most common hospital-acquired infections $^{(8-10)}$. It is stated that $70 \%-80 \%$ of patients with urinary catheter would have urinary tract infection. When nurses are not equipped with the necessary knowledge and practices related to proper urinary catheter care and application of infection control measures or they neglect their application during the procedure, so the percentages of UTI becomes high.

\section{Aim of the Study}

Assess nurses' application of infection control measures related to urinary catheter care.

\section{Research Questions:}

1. What is the level of nurses' knowledge related to infection control measures while caring for patient with urinary catheter?

2. What is the level of nurses' practices related to infection control measures while caring for patient with urinary catheter?

3. What is the nurses' attitude toward performing urinary catheter care and application of infection control measures?

\section{Materials and Method}

\section{Materials}

Design: Descriptive research design was used to conduct this study.

Setting: This study was conducted in the 3 ICUs, 2 medical, 2 surgical units and 3 from urology ward in the National Institute of Kidney Diseases- Cairo Governorate.

Subjects: All nurses available at the time of data collection and working for at least one year in the previous settings and accept to participate in the study were included in the sample, their number amounted to 67 nurses: 46 from ICUs, 10 from the medical, 8 from the surgical wards and 3 from urology ward.

Tools: Four tools were used for data collection:

Tool I: Nurses' socio-demographic data and occupation profile structured schedule

This tool was developed by the researchers: It contains (6) items used to assess nurses' demographic data as; gender, age, qualification, years of experience, attending infection control courses, and working unit.

Tool II: Nurses' knowledge selfadministered questionnaire

This tool was developed by the researchers after reviewing of different related literatures to assess nurses' 
knowledge about urinary catheter care and infection control measures that should be implemented, in caring for urinary catheter as; indications for urinary catheter insertion, signs and symptoms of urinary tract infection, principles of aseptic technique and universal precautions for infection control. The scoring system for nurses' level of knowledge was as follows: the correct response was scored 1 and the incorrect zero. The scores of the items were summedup and the total divided by the number of items, giving a mean score for the part. Knowledge evaluation was as follows; $75 \%$ or more was considered satisfactory, $60 \%$ to $<74 \%$ average and below $60 \%$ unsatisfactory.

Tool III: Nurses' performance observation checklist for urinary catheter care

It is adopted from Miller (2015) ${ }^{(11)}$ and it was modified by the researchers to assess nursing care for patients connected with urinary catheter and application of infection control measures while providing such care. It contains nursing care pre, during and post urinary catheter care. The scoring system for the observational checklist for nurses' practice was as follows; "Done completely equal 3" "Done partially 2" and "not done $1 "$. For each part, the scores of the items were summed-up and the total divided by the number of items, giving a mean score for the part. The practice level of the nurses was considered satisfactory if the percent score was $75 \%$ or more, $60 \%$ to $<74 \%$, average, and below $60 \%$ unsatisfactory.

Tool IV: Nurses' attitude toward urinary catheter care and application of infection control measures

This tool was developed by the researchers; it was used to assess nurses' attitudes toward caring of patients with urinary catheter and application of infection control measures. The scoring system of the above mentioned tool was as follows; Nurses' attitude scores were categorized into 3 categories; "agree 3", "uncertain 2", and "disagree 1", if the nurses their answers were 3 , the score was reversed for positive attitude. If nurses their answers were uncertain, the score was considered as neutral attitude, and if their answers were disagree, the score was reversed for negative attitude. The scores of items were summedup and the total divided by the number of the items, giving a mean score. The attitude was considered positive if the percent score was $60 \%$ or more and negative if less than $60 \%$.

\section{Method}

- An official letter was issued from the Faculty of Nursing Dean, and delivered to the Director of the National Institute of Kidney Diseases, in order to obtain the approval to conduct the study after explaining its purpose.

- Content validity of the data collection tools was done by 3 experts in the related fields namely medical surgical nursing ( 2 experts Faculty of NursingAin Shams University) and (1 expert from Faculty of Nursing-Cairo University).

- The reliability coefficient of the tools was calculated using by Cronbach's alpha through SPSS and it was as follows; for knowledge questionnaire $=88.9$, for attitude tool $=90.2$, and for observation checklist tool $=88.9$.

- The pilot study was carried out on a sample of 8 nurses (10\%) from nurses working in the National Institute of Kidney Diseases to check and ensure the clarity and applicability of the tools. Based on the findings correction were done. These nurses were not included in the study subjects.

- The setting of the study was visited by the researcher two days per week from 9:00 a.m. to 2:00 p.m.

- Permission was obtained from all participants of the study after explanation of the study purpose. The 
researcher interviewed each nurse and explained the process of data collection. After assessing their sociodemographic data and occupation profile using tool I then knowledge questionnaire about urinary catheter care and application of infection control measures tool II, and nurses' attitude tool IV were distributed.

- Knowledge questionnaire was completed in 20 minutes, and attitude in 15 minutes.

- The nurses were informed that there will be another visit by the researchers to observe them while performing urinary catheter care and applying infection control measures.

- With regard to filling in the observational checklist tool; the researcher assessed each nurse using the observational checklist while she/he is providing urinary catheter care for patients and each nurse was observed once.

- The number of interviewed nurses per week ranged from 1-2 nurses.

- The study was carried out over a period of 6 months from the beginning of March 2017 to the end of September 2017.

\section{Ethical considerations:}

After explaining aim of the study and data collection tools to the research committee in the University, and to the hospital administration, the following approvals were obtained as follows; first from the Ethical Research Committee in the University, then the hospital administration, and finally from the nurses who agreed to participate in the study, and they asked to sign a consent form to confirm their acceptance to participate in the study. In addition, the nurses were ensured about the confidentiality of their data. As well as the researcher assured them that participation in this study was voluntary, the nurses were informed that they have the right to withdraw from the study at any time, and data collections tools will be anonymity. The researcher committed that, there is no any harmful effect for any one and it will beneficial for the nurses and the hospital administration. In addition, the findings will be discussed with hospital management team before publishing its results.

\section{Statistical Analysis}

Statistical analysis was done using computer software, by using the Statistical Package for Social Sciences (SPSS) version (20) that was used for this purpose. Descriptive correlation statistics were applied (Mean, Standard Deviation, Frequency and Percentage) test of significance (Chi-square) was used to test significance between variables. A statistically significant difference was considered at $\mathrm{P}$-value $\leq 0.05$, and a highly statistically significant difference was considered at $\mathrm{P}$-value $\leq 0.001$.

\section{Results}

Table (1) reveals the age of the studied nurses ranges from 20 to 35 years with a mean of $26.9 \pm 5.94$. Females constituted $79.1 \%$. In relation to nurses' qualification, almost half $(47.8 \%)$ of the nurses had a Bachelor degree, $26.9 \%$ secondary nursing diploma, and $25.4 \%$ technical nursing diploma. With regard to years of experience, the current study result shows that, the mean years of experience was 5.53 \pm 5.8 . Meanwhile, $68.7 \%$, of the nurses work in ICU, $14.9 \%$, and $11.9 \%$, in the medical and surgical wards respectively. In relation to attending training courses, $76.1 \%$ of the studied sample attended training courses related to infection control.

Table (2) shows that $32.8 \%$, of the nurses had satisfactory knowledge, $37.3 \%$ and $29.9 \%$ of the studied sample had average and unsatisfactory levels of knowledge in relation to urinary catheter care and application of infection control measures respectively. 
Table (3) indicates that $39.10 \%, 20.1 \%$ and $40.8 \%$ on the participants had either satisfactory or average or unsatisfactory levels of practices as regard the preparation of patients before the insertion of urinary catheter and application of infection control measures respectively. Meanwhile, $62.9 \%$, $6.3 \%$, and $30.8 \%$ of them had either satisfactory, or average or unsatisfactory levels of practice during the procedure. While the nursing measures applied post procedure, the results revealed that, $77.6 \%$, $4.2 \%$, and $21.9 \%$ of the studied sample had either satisfactory, or average and or unsatisfactory levels of practice.

Table (4) reports that $59.2 \%, 8.9 \%$, and $31.9 \%$ of the studied sample had either satisfactory, or average or unsatisfactory level of practice in relation to applying both urinary catheter care and infection control measures respectively.

Table (5) reveals that $77.6 \%$ of the studied nurses had positive attitude toward urinary catheter care and application of infection control measures and $22.4 \%$ were uncertain. None of them had negative attitude.

Table (6) reveals no statistically significant relations between nurses' level of knowledge and gender, age, years of experiences or qualification. However, statistically significant relations were observed between work place, and attending training courses related to infection control and knowledge of the studied sample $\mathrm{P}<0.05 \& \leq 0.001$ respectively.

Table (7) reveals that statistically significant relations between nurses' attitude toward urinary catheter care and application of infection control measures, and work place, and attending training courses at $\mathrm{P} \leq 0.001 \&<0.05$ respectively.

Table (8) reveals that, there are highly statistically significant relations between nurses' practice and work place, and attending training courses about infection control measures with $\mathrm{P} \leq 0.001$ and $<0.05$ respectively.
Table (9) indicates that there is a statistical significantly relation between the nurses' knowledge and practice in relation to urinary catheter care and application of infection control measures with $\mathrm{P} \leq 0.001$.

Tables (10, 11) show that there are highly statistically significant relations between practice of the studied sample, and their attitude, and knowledge with $\mathrm{P} \leq 0.001$.

\section{Discussion}

Urinary catheter care is an important practice performed by nurses through following the infection control measures during care to prevent transmission of infection, as urinary tract infection is considered the most common transmitted nosocomial infection.

As indicated in this study, almost two third of the studied sample had satisfactory level of knowledge in most items related to urinary catheter care and application of infection control measures (Table 2). This could be attributed to that the nurses are realizing the importance of application of the infection control measures and therefore they keep themselves up-to- date by knowledge related infection control measures while caring of urinary catheter. In addition, the hospital administration believes in upgrading their nurses' performance by conducting in-services training and hand training for them.

In addition, the majority of the studied sample works in ICU and due to the nature of ICU from perspective of the patients' condition, all patients are at high risk for acquiring infection from different sources and from invasive procedures. This finding was in agreement with that of Drekonja et al. $(2010)^{(12)}$, Oman et al. $(2011)^{(10)}$, Miller $(2015)^{(11)}$ who stated that it is essential for all nurses to attend training courses generally and infection control measures specifically in order to be provided by necessary knowledge in such field.

The current study findings mentioned that, almost three fifth of the studied sample had satisfactory level of practice with regard 
to urinary catheter care and application of infection control measures, while less than tenth of them had average level of practice in the observed skill items (Table 4). This might be interpreted as; although with different years of experience the nurses who participated in this study had different levels of qualifications, they work in ICU which is concerned about training of their staff on different important and essential topics as infection control. This finding is contrasting with those of Mody et al. (2011) ${ }^{(7)}$ who reported that, encouraging nursing staff to follow standardized guidelines and attend training courses could facilitate for them practicing competently as well as enhancing nurses to upgrade themselves and this will promote their interventions, while providing care to the patients in relation to any nursing skills.

The present study showed that, the majority of the studied sample agreed that, urinary catheter and application of infection control measures could prevent urinary tract infection associated with urinary catheter, and overall three quarter of them had positive attitude toward urinary catheter care and application of infection control measures (Table 5). This might be explained as the nurses who are well trained and educated about infection control measures are fully aware of the importance of application of infection control measures. In the same line with this finding, Jain et al. $(2015)^{(13)}$ who proved that, the majority of health care givers including nurses believe that, continuous education and training provide them by the adequate knowledge that makes them fully aware about the importance of effectiveness of infection control measures to prevent urinary tract infection.

The present study showed that, there was a statistically significant relation between nurses' knowledge and their work place and attending training courses for infection control (Table 6). This could be attributed to that, due to the nature of ICU as a work place and seriousness of the cases, the nurses are keen to acquire more knowledge in order to be able to protect patients from infection as well protect themselves, which encourage them to attend more training courses. In the same context with this finding, Jain et al. $(2015)^{(13)}$ who mentioned that, most of health care providers including nurses believe that, education and training regarding urinary catheter care and application of infection control measures could improve their performance and it is considered as a definitive evidence for preventing urinary tract infection associated with urinary catheter, they added that, when the hospital focuses on education and training of the nurses and considers both as high priority this would help in controlling infection in general and urinary tract infection specifically.

The current study revealed that, there was highly statistically significant relation between nurses' attitude and their work place and attending training courses for infection control (Table 7). This might be due to that, when the nurses working in well setup place with adequate supplies and facilities, this will reflect positively on their feeling during provision of care. This finding is supported by El-Sayed et al. $(2015)^{(8)}$ who mentioned that, feeling comfort in work place, and having adequate knowledge lead to acceptance and enjoying nursing practice.

This study revealed that, there was highly statistically significant relation between nurses' practice and their work place and attending training courses for infection control (Table 8). This might be due to that, the nature of cases in ICUs needs well qualified nurses in practice in order to be able to handle such cases. This result is in the same line with Lo et al. $(2014)^{(9)}$ who reported that, working in ICUs needs special qualifications and good level of practice among nurses in order to be able to provide nursing care for critical cases.

In this study, finding revealed that, there was highly statistically significant relation between knowledge, practice and 
attitude of the studied sample toward caring of urinary catheter and applications of infection control measures (Tables 9, 10, and 11). In the same line of this finding, Sessa et al. $(2011)^{(14)}$, Galiczewski and Shurpin $(2017)^{(15)}$ who clarified that, knowledge and additional training courses about infection control have the strongest significant effect on nurses which let them have positive attitude toward care provided to the patients.

\section{Conclusion}

This study concluded that, the nurses who attended training courses their knowledge, practice are much better than those who did not. Moreover, the current study revealed that, good level of knowledge and practice reflects positively on nurses' attitude and encourage them to adhere to the hospital policies and work efficiently.

\section{Recommendations}

The current study recommended that, there is a need for continuous education and reinforcement of positive attitudes in relation to urinary catheter care and application of infection control measures. In addition, all nurses in different units and wards in the hospital should attend training courses in relation to their specialty as well their needs.

\section{Limitations of the Study}

The main limitation the researchers faced in this study was the small number of the study sample, so the results could not be generalized.

\section{Acknowledgment}

The authors thank all nurses who participated in this study and special thanks for the administration authority at the National Institute of Kidney Disease for allowing conducting this study. 
Table (1): Distribution of nurses according to their demographic data and work profile data $(n=67)$

\begin{tabular}{|c|c|c|}
\hline Items & No. $=67$ & $\%$ \\
\hline $\begin{array}{l}\text { Gender } \\
\text { Female } \\
\text { Male }\end{array}$ & $\begin{array}{l}53 \\
14\end{array}$ & $\begin{array}{l}79.1 \\
20.9\end{array}$ \\
\hline $\begin{array}{l}\text { Age } \\
20-24 \\
25-30 \\
31-35 \\
35+ \\
\end{array}$ & $\begin{array}{c}37 \\
18 \\
5 \\
7 \\
\end{array}$ & $\begin{array}{c}55 \\
26.8 \\
7.8 \\
10.4 \\
\end{array}$ \\
\hline$\overline{\mathbf{x}} \pm$ SD & $26.9 \pm 5.9$ & \\
\hline $\begin{array}{l}\text { Qualifications } \\
\text { Bachelor degree } \\
\text { Secondary nursing diploma } \\
\text { Technical Institute of Nursing }\end{array}$ & $\begin{array}{l}32 \\
18 \\
17\end{array}$ & $\begin{array}{l}47.8 \\
26.9 \\
25.4\end{array}$ \\
\hline $\begin{array}{l}\text { Years of Experience } \\
1-3 \\
4-6 \\
7-10 \\
10+\end{array}$ & $\begin{array}{l}34 \\
16 \\
8 \\
9\end{array}$ & $\begin{array}{l}50.7 \\
23.9 \\
11.9 \\
13.5\end{array}$ \\
\hline$\overline{\mathbf{x}} \pm$ SD & $5.53 \pm 5.8$ & \\
\hline $\begin{array}{l}\text { Work place } \\
\text { ICU } \\
\text { Medical wards } \\
\text { Surgical wards } \\
\text { Urology ward }\end{array}$ & $\begin{array}{c}46 \\
10 \\
8 \\
3\end{array}$ & $\begin{array}{c}68.7 \\
14.9 \\
11.9 \\
4.5\end{array}$ \\
\hline $\begin{array}{l}\text { Attended infection control courses } \\
\text { Yes } \\
\text { No }\end{array}$ & $\begin{array}{l}51 \\
16\end{array}$ & $\begin{array}{l}76.1 \\
23.9\end{array}$ \\
\hline
\end{tabular}

Table (2): Distribution of nurses according to their level of knowledge in relation to urinary catheter care and application of infection control measures $(n=67)$

\begin{tabular}{|l|c|c|}
\hline Level of knowledge & No.=67 & \% \\
\hline Satisfactory knowledge $(\leq 75 \%)$ & 22 & 32.8 \\
\hline Average knowledge $(60 \%$ to $<74 \%)$ & 25 & 37.3 \\
\hline Unsatisfactory knowledge $(>60 \%)$ & 20 & 29.9 \\
\hline Total & $\mathbf{6 7}$ & $\mathbf{1 0 0}$ \\
\hline
\end{tabular}


Table (3): Distribution of nurses' practices throughout urinary catheter care procedure $(n=67)$

\begin{tabular}{|c|c|c|c|c|c|c|}
\hline \multirow[t]{2}{*}{ Assessment items } & \multicolumn{2}{|c|}{$\begin{array}{l}\text { Satisfactory } \\
\text { Practice }\end{array}$} & \multicolumn{2}{|c|}{$\begin{array}{l}\text { Average } \\
\text { Practice }\end{array}$} & \multicolumn{2}{|c|}{$\begin{array}{l}\text { Unsatisfacto } \\
\text { ry Practice }\end{array}$} \\
\hline & No & $\%$ & No & $\%$ & No & $\%$ \\
\hline \multicolumn{7}{|l|}{ Pre procedure: } \\
\hline Verify physician prescription & 0 & 0.00 & 0 & 0 & 67 & 100 \\
\hline Wash hands & 31 & 46.3 & 0 & 0 & 36 & 53.7 \\
\hline Prepare equipment & 0 & 0.00 & 67 & 100 & 0 & 0 \\
\hline Introduce yourself to patient & 38 & 56.7 & 0 & 0 & 29 & 43.3 \\
\hline Identify patient & 47 & 70.1 & 0 & 0 & 20 & 29.9 \\
\hline Explain procedure to the patient & 41 & 61.2 & 0 & 0 & 26 & 38.8 \\
\hline Keep patient privacy & 0 & 0 & 67 & 100 & 0 & 0 \\
\hline Adjust the height of the bed & 43 & 64.2 & 0 & 0 & 24 & 35.8 \\
\hline Disinfect hands & 31 & 46.3 & 0 & 0 & 36 & 53.7 \\
\hline Wear clean gloves & 31 & 46.3 & 0 & 0 & 36 & 53.7 \\
\hline $\begin{array}{l}\text { Total No. of responses in this category }=10 x \\
67=670\end{array}$ & 262 & $\begin{array}{c}39.1 \\
0\end{array}$ & 134 & 20.1 & 274 & $\overline{40.8}$ \\
\hline \multicolumn{7}{|l|}{ During procedure: } \\
\hline Clamp urinary catheter first by artery. & 0 & 0 & 0 & 0 & 67 & 100 \\
\hline Lower side rails of the bed in your side & 0 & 0 & 0 & 0 & 67 & 100 \\
\hline Fold the patient gown until waist & 0 & 0 & 67 & 100 & 0 & 0 \\
\hline Turn patient in one side (raise side rail up) & 44 & 65.7 & 0 & 0 & 23 & 34.3 \\
\hline Put absorbed sheet under the patient & 45 & 67.2 & 0 & 0 & 22 & 32.8 \\
\hline Reposition the patient in his/her back & 50 & 74 & 0 & 0 & 17 & 25.4 \\
\hline Expose the perineal area & 54 & 80.6 & 0 & 0 & 13 & 19.4 \\
\hline Assess presence of discomfort from the catheter. & 52 & 77.6 & 0 & 0 & 15 & 22.4 \\
\hline $\begin{array}{l}\text { Wash the urinary meatus/labia and dry it in the } \\
\text { correct direction }\end{array}$ & 45 & 67.2 & 0 & 0 & 22 & 32.8 \\
\hline Wash the external part of the urinary catheter & 56 & 83.6 & 0 & 0 & 11 & 16.4 \\
\hline Remove and discard gloves and wear another pair & 51 & 76.1 & 0 & 0 & 16 & 23.9 \\
\hline Turn patient in one side with the side rail up & 42 & 62.7 & 0 & 0 & 25 & 37.3 \\
\hline Place a paper on the floor below the urinary bag & 51 & 76.1 & 0 & 0 & 16 & 23.9 \\
\hline Carefully empty the urine from urine bag. & 55 & 82.1 & 0 & 0 & 12 & 17.9 \\
\hline $\begin{array}{l}\text { Clamp the bag and disinfect the clamp end using } \\
\text { alcohol swab. }\end{array}$ & 55 & 82.1 & 0 & 0 & 12 & 17.9 \\
\hline Hang the tube in proper place. & 52 & 77.6 & 0 & 0 & 15 & 22.4 \\
\hline Fix the urinary bag appropriately & 44 & 65.7 & 13 & 19.4 & 10 & 14.9 \\
\hline Open urinary catheter clamp & 49 & 73.1 & 0 & 0 & 18 & 26.9 \\
\hline $\begin{array}{l}\text { Place the side rail up and return the bed into } \\
\text { proper height }\end{array}$ & 56 & 83.6 & 0 & 0 & 11 & 16.4 \\
\hline $\begin{array}{l}\text { Total No. of responses in this category }=19 x \\
67=1273\end{array}$ & 801 & 62.9 & 80 & 6.3 & 392 & $\mathbf{3 0 . 8}$ \\
\hline \multicolumn{7}{|l|}{ Post procedure: } \\
\hline Dispose any used materials & 64 & 95.5 & 0 & 0 & 3 & 4.5 \\
\hline Keep and clean equipment & 48 & 71.6 & 0 & 0 & 19 & 28.4 \\
\hline Remove gloves & 48 & 71.6 & 0 & 0 & 19 & 28.4 \\
\hline Wash hands & 48 & 71.6 & 0 & 0 & 19 & 28.4 \\
\hline Record the procedure & 48 & 71.6 & 0 & 0 & 19 & 28.4 \\
\hline $\begin{array}{l}\text { Report any abnormalities at the site of insertion as } \\
\text { (redness, inflammation, discharge, odor) }\end{array}$ & 57 & 85.1 & 1 & 1.5 & 9 & 13.4 \\
\hline $\begin{array}{l}\text { Assess urine for any abnormalities as; change in } \\
\text { color, consistency, or odor }\end{array}$ & 51 & 76.1 & 1 & 1.5 & 15 & 22.4 \\
\hline Total No. of responses $=7 \times 67=469$ & 364 & 77.6 & 2 & 4.2 & 103 & 21.9 \\
\hline
\end{tabular}


Table (4): Distribution of nurses' practice throughout urinary catheter care procedure $(n=67)$

\begin{tabular}{||l|c|c|c|c|c|c||}
\hline \multirow{2}{*}{ Assessment items } & \multicolumn{2}{|c|}{$\begin{array}{c}\text { Satisfactory } \\
\text { practice } \\
(\leq 75 \%)\end{array}$} & \multicolumn{2}{c|}{$\begin{array}{c}\text { Average } \\
\text { practice } \\
(60 \% \text { to }<74 \%)\end{array}$} & \multicolumn{2}{c||}{$\begin{array}{c}\text { Unsatisfactory } \\
\text { practice } \\
(>60 \%)\end{array}$} \\
\cline { 2 - 8 } & $\mathbf{N o}$ & $\mathbf{\%}$ & $\mathbf{N o}$ & $\%$ & No & $\%$ \\
\hline Before Procedure & 262 & 39.10 & 134 & 20.1 & 274 & 40.8 \\
\hline During Procedure & 801 & 62.9 & 80 & 6.2 & 392 & 30.7 \\
\hline After Procedure & 364 & 77.6 & 2 & 4.2 & 103 & 21.9 \\
\hline $\begin{array}{l}\text { Total No. of responses= 36 x 67= 2412 } \\
\% \\
\text { x of each category = total of each category } \\
\mathbf{1 0 0 / 2 4 1 2}\end{array}$ & $\mathbf{1 4 2 7}$ & $\mathbf{5 9 . 2}$ & $\mathbf{2 1 6}$ & $\mathbf{8 . 9}$ & $\mathbf{7 6 9}$ & $\mathbf{3 1 . 9}$ \\
\hline
\end{tabular}

Table (5): Distribution of nurses' attitude toward urinary catheter care and application of infection control measures $(n=67)$

\begin{tabular}{|l|c|c||}
\hline \hline Attitude & No.= 67 & \% \\
\hline Positive attitude & 52 & 77.6 \\
\hline Uncertain attitude & 15 & 22.4 \\
\hline Negative attitude & 0 & 0.00 \\
\hline Total & $\mathbf{6 7}$ & $\mathbf{1 0 0}$ \\
\hline
\end{tabular}


Table (6): Relation between nurses demographic data and their knowledge about infection control measures and caring of urinary catheter $(n=67)$

\begin{tabular}{|c|c|c|c|c|c|c|c|c|}
\hline \multirow[t]{2}{*}{ Demographic data } & \multicolumn{2}{|c|}{$\begin{array}{c}\text { Satisfactory } \\
\text { knowledge }\end{array}$} & \multicolumn{2}{|c|}{$\begin{array}{c}\text { Average } \\
\text { knowledge }\end{array}$} & \multicolumn{2}{|c|}{$\begin{array}{c}\text { Unsatisfactory } \\
\text { knowledge }\end{array}$} & \multirow{5}{*}{$\frac{X^{2}}{1.474}$} & \multirow{5}{*}{$\begin{array}{c}\text { P- Value } \\
\mathbf{0 . 4 7 8} \\
(>0.05) \\
\text { Not significant }\end{array}$} \\
\hline & No. & $\%$ & No. & $\%$ & No. & $\%$ & & \\
\hline \multicolumn{7}{|l|}{ Gender } & & \\
\hline Female & 19 & 36 & 18 & 34 & 16 & 30 & & \\
\hline Male & 3 & 21.5 & 7 & 50 & 4 & 28.5 & & \\
\hline \multicolumn{9}{|l|}{ Age } \\
\hline $20-24$ & 9 & 16 & 12 & 32.4 & 16 & 43.3 & \multirow[t]{4}{*}{34.655} & \multirow{4}{*}{$\begin{array}{c}\mathbf{0 . 4 3 7} \\
(>0.05) \\
\text { Not significant }\end{array}$} \\
\hline $25-30$ & 9 & 50 & 6 & 33 & 3 & 17 & & \\
\hline $31-35$ & 0 & 00.0 & 4 & 80 & 3 & 60 & & \\
\hline $35+$ & 4 & 57 & 3 & 43 & 0 & 00.0 & & \\
\hline \multicolumn{9}{|l|}{ Years of experience } \\
\hline $1-3$ & 7 & 21 & 12 & 35 & 15 & 44 & \multirow[t]{4}{*}{30.285} & \multirow{4}{*}{$\begin{array}{c}\mathbf{0 . 4 5 1} \\
(>0.05) \\
\text { Not significant }\end{array}$} \\
\hline $4-6$ & 8 & 50 & 6 & 38 & 2 & 12.5 & & \\
\hline $7-10$ & 4 & 50 & 2 & 25 & 2 & 25 & & \\
\hline $10+$ & 3 & 33.3 & 5 & 56 & 1 & 11 & & \\
\hline \multicolumn{9}{|l|}{ Qualifications } \\
\hline Secondary Diploma & 6 & 33 & 7 & 39 & 5 & 28 & \multirow[t]{3}{*}{3.712} & \multirow{3}{*}{$\begin{array}{c}\mathbf{0 . 4 4 6} \\
(>0.05) \\
\text { Not significant }\end{array}$} \\
\hline $\begin{array}{l}\text { Technical nursing } \\
\text { diploma }\end{array}$ & 5 & 29 & 4 & 24 & 8 & 47 & & \\
\hline Bachelor & 11 & 34 & 14 & 44 & 7 & 22 & & \\
\hline \multicolumn{9}{|l|}{ Work place } \\
\hline ICU & 20 & 43 & 17 & 37 & 9 & 19.5 & \multirow[t]{4}{*}{13.580} & \multirow{4}{*}{$\begin{array}{c}\mathbf{0 . 0 3 5} \\
(<0.05) \\
\text { Significant }\end{array}$} \\
\hline Medical wards & 0 & 00.0 & 3 & 30 & 7 & 70 & & \\
\hline Surgical wards & 1 & 12.5 & 4 & 50 & 3 & 37.5 & & \\
\hline Urology ward & 1 & 33 & 1 & 33 & 1 & 33 & & \\
\hline \multicolumn{9}{|c|}{ Attending infection control courses } \\
\hline Yes & 20 & 39 & 23 & 45 & 8 & 15.6 & \multirow[t]{2}{*}{20.470} & \multirow{2}{*}{$\begin{array}{c}\mathbf{0 . 0 0 0} \\
(\leq \mathbf{0 . 0 0 1}) \\
\text { Highly } \\
\text { significant } \\
\end{array}$} \\
\hline No & 2 & 12.5 & 2 & 12.5 & 12 & 75 & & \\
\hline
\end{tabular}


Table (7): Relation between nurses demographic data and their attitude about infection control measures and caring of urinary catheter $(n=67)$

\begin{tabular}{|c|c|c|c|c|c|c|}
\hline \multirow[t]{2}{*}{ Demographic data } & \multicolumn{2}{|c|}{$\begin{array}{l}\text { Positive } \\
\text { attitude }\end{array}$} & \multicolumn{2}{|c|}{$\begin{array}{c}\text { Uncertain } \\
\text { attitude }\end{array}$} & $\mathrm{X}^{2}$ & P-Value \\
\hline & No & $\%$ & No & $\%$ & \multirow[t]{4}{*}{0.009} & \multirow{4}{*}{$\begin{array}{c}\mathbf{0 . 9 2 3} \\
(>0.05) \\
\text { Not significant }\end{array}$} \\
\hline \multicolumn{5}{|l|}{ Gender } & & \\
\hline Female & 41 & 77 & 12 & 23 & & \\
\hline Male & 11 & 79 & 3 & 21 & & \\
\hline \multicolumn{7}{|l|}{ Age } \\
\hline $20-24$ & 28 & 76 & 9 & 24 & \multirow[t]{4}{*}{20.236} & \multirow{4}{*}{$\begin{array}{c}0.262 \\
(>0.05) \\
\text { Not significant }\end{array}$} \\
\hline $25-30$ & 13 & 72 & 5 & 28 & & \\
\hline $31-35$ & 4 & 80 & 1 & 20 & & \\
\hline $35+$ & 7 & 100 & 0 & 00.0 & & \\
\hline \multicolumn{7}{|l|}{ Years of experience } \\
\hline $1-3$ & 24 & 71 & 10 & 29 & \multirow[t]{4}{*}{15.652} & \multirow{4}{*}{$\begin{array}{c}\mathbf{0 . 4 0 6} \\
(>0.05) \\
\text { Not } \text { significant }\end{array}$} \\
\hline $4-6$ & 14 & 88 & 2 & 12.5 & & \\
\hline $7-10$ & 6 & 75 & 2 & 25 & & \\
\hline $10+$ & 8 & 89 & 1 & 11.1 & & \\
\hline \multicolumn{7}{|l|}{ Qualification } \\
\hline Secondary Diploma & 11 & 61 & 7 & 39 & \multirow[t]{3}{*}{3.883} & \multirow{3}{*}{$\begin{array}{c}\mathbf{0 . 1 4 3} \\
(>0.05) \\
\text { Not significant }\end{array}$} \\
\hline Technical nursing diploma & 14 & 82 & 3 & 17.6 & & \\
\hline Bachelor & 27 & 84.4 & 5 & 15.6 & & \\
\hline \multicolumn{7}{|l|}{ Work place } \\
\hline ICU & 41 & 89.2 & 5 & 10.8 & \multirow[t]{4}{*}{12.912} & \multirow{4}{*}{$\begin{array}{c}\mathbf{0 . 0 0 5} \\
(\leq \mathbf{0 . 0 0 1}) \\
\text { Highly } \\
\text { significant }\end{array}$} \\
\hline Medical wards & 4 & 40 & 6 & 60 & & \\
\hline Surgical wards & 5 & 62.5 & 3 & 37.5 & & \\
\hline Urology ward & 2 & 67 & 1 & 33 & & \\
\hline \multicolumn{7}{|c|}{ Attending infection control courses } \\
\hline Yes & 44 & 86.3 & 7 & 13.7 & \multirow[t]{2}{*}{9.223} & \multirow{2}{*}{$\begin{array}{c}\mathbf{0 . 0 0 2} \\
(<0.05) \\
\text { Significant }\end{array}$} \\
\hline No & 8 & 50 & 8 & 50 & & \\
\hline
\end{tabular}


Table (8): Relation between nurses demographic data and their practice about infection control measures and caring of urinary catheter $(n=67)$

\begin{tabular}{|c|c|c|c|c|c|c|c|c|}
\hline \multirow[t]{2}{*}{ Demographic Data } & \multicolumn{2}{|c|}{$\begin{array}{c}\text { Satisfactory } \\
\text { practice }\end{array}$} & \multicolumn{2}{|c|}{$\begin{array}{l}\text { Average } \\
\text { practice }\end{array}$} & \multicolumn{2}{|c|}{$\begin{array}{c}\text { Unsatisfactory } \\
\text { practice }\end{array}$} & \multirow{2}{*}{$\begin{array}{c}\mathrm{X}^{2} \\
2.026\end{array}$} & \multirow{4}{*}{$\begin{array}{c}\text { P- Value } \\
0.363 \\
(>0.05) \\
\text { Not } \\
\text { significant }\end{array}$} \\
\hline & No & $\%$ & No & $\%$ & No & $\%$ & & \\
\hline \multicolumn{7}{|l|}{ Gender } & & \\
\hline Female & 34 & 64.2 & 13 & 24.5 & 6 & 11.3 & & \\
\hline Male & 11 & 79 & 1 & 7 & 2 & 14 & & \\
\hline \multicolumn{9}{|l|}{ Age } \\
\hline $20-24$ & 24 & 64.8 & 10 & 27.2 & 3 & 8.10 & \multirow[t]{4}{*}{35.949} & \multirow{4}{*}{$\begin{array}{c}\mathbf{0 . 3 7 7} \\
(>0.05) \\
\text { Not } \\
\text { significant }\end{array}$} \\
\hline $25-30$ & 11 & 61.2 & 3 & 16.6 & 4 & 22.2 & & \\
\hline $31-35$ & 4 & 80 & 0 & 00.0 & 1 & 20 & & \\
\hline $35+$ & 6 & 85.7 & 1 & 14.3 & 0 & 00.0 & & \\
\hline \multicolumn{9}{|l|}{ Years of experience } \\
\hline $1-3$ years & 21 & 61.9 & 11 & 32.3 & 2 & 5.8 & \multirow[t]{4}{*}{31.919} & \multirow{4}{*}{$\begin{array}{c}0.371 \\
(>0.05) \\
\text { Not } \\
\text { significant }\end{array}$} \\
\hline 4-6 years & 11 & 68.7 & 2 & 12.5 & 3 & 18.8 & & \\
\hline $7-10$ years & 6 & 75 & 0 & 00.0 & 2 & 25 & & \\
\hline $10+$ & 7 & 78 & 1 & 11.1 & 1 & 11.1 & & \\
\hline \multicolumn{9}{|l|}{ Qualification } \\
\hline Secondary Diploma & 12 & 67 & 5 & 27.7 & 1 & 5.5 & \multirow[t]{3}{*}{2.259} & \multirow{3}{*}{$\begin{array}{c}\mathbf{0 . 6 8 8} \\
(>0.05) \\
\text { Not } \\
\text { significant }\end{array}$} \\
\hline $\begin{array}{l}\text { Technical nursing } \\
\text { diploma }\end{array}$ & 10 & 58 & 4 & 24 & 3 & 18 & & \\
\hline Bachelor & 23 & 71.8 & 5 & 15.6 & 4 & 12.6 & & \\
\hline \multicolumn{9}{|l|}{ Work place } \\
\hline ICU & 36 & 78 & 4 & 9 & 6 & 13 & \multirow[t]{4}{*}{21.925} & \multirow{4}{*}{$\begin{array}{c}\text { 0.001 } \\
(\leq \mathbf{0 . 0 0 1 )} \\
\text { Highly } \\
\text { significant }\end{array}$} \\
\hline Medical wards & 2 & 20 & 7 & 70 & 1 & 10 & & \\
\hline Surgical wards & 4 & 50 & 3 & 37.5 & 1 & 12.5 & & \\
\hline Urology ward & 3 & 100 & 0 & 00.0 & 0 & 00.0 & & \\
\hline \multicolumn{9}{|c|}{ Attending infection control courses } \\
\hline Yes & 40 & 78.5 & 7 & 13.7 & 4 & 7.8 & \multirow[t]{2}{*}{12.293} & \multirow{2}{*}{$\begin{array}{c}0.002 \\
(<0.05) \\
\text { Significan }\end{array}$} \\
\hline No & 5 & 31.3 & 7 & 43.7 & 4 & 25 & & \\
\hline
\end{tabular}


Table (9): Relation between levels of knowledge of the studied sample and their practices about infection control measures and urinary catheter care $(n=67)$

\begin{tabular}{|c|c|c|c|c|c|}
\hline \multirow{3}{*}{$\begin{array}{l}\text { Levels of } \\
\text { knowledge }\end{array}$} & \multicolumn{3}{|c|}{ Levels of practice } & \multirow[b]{2}{*}{$\mathbf{X}^{2}$} & \multirow[b]{2}{*}{ P-Value } \\
\hline & Satisfactory & Average & Unsatisfactory & & \\
\hline & No & No & No & \multirow{5}{*}{20.358} & \multirow{5}{*}{$\begin{array}{c}0.000 \\
(\leq 0.001) \\
\text { Highly } \\
\text { significan }\end{array}$} \\
\hline Satisfactory & 20 & 1 & 1 & & \\
\hline Average & 19 & 5 & 1 & & \\
\hline Unsatisfactory & 6 & 8 & 6 & & \\
\hline Total & 45 & 14 & 8 & & \\
\hline
\end{tabular}

Table (10): Relation between nurses' level of practice toward application of infection control measures and urinary catheter care and their attitude $(n=67)$

\begin{tabular}{|c|c|c|c|c|}
\hline \multirow{3}{*}{ Levels of practice } & \multicolumn{2}{|c|}{ Attitude category } & \multirow[b]{2}{*}{$\mathbf{X}^{2}$} & \multirow[b]{2}{*}{ P- Value } \\
\hline & Positive attitude & Uncertain & & \\
\hline & No & No & \multirow{4}{*}{21.596} & \multirow{4}{*}{$\begin{array}{c}\mathbf{0 . 0 0 0} \\
(\leq \mathbf{0 . 0 0 1}) \\
\text { Highly } \\
\text { significant }\end{array}$} \\
\hline Satisfactory & 42 & 3 & & \\
\hline Average & 5 & 9 & & \\
\hline Unsatisfactory & 3 & 3 & & \\
\hline
\end{tabular}

Table (11): Relation between levels of knowledge of the studied sample and their attitude toward application of infection control measures and urinary catheter care $(n=67)$

\begin{tabular}{|c|c|c|c|c|}
\hline \multirow{3}{*}{$\begin{array}{l}\text { Levels of } \\
\text { knowledge }\end{array}$} & \multicolumn{2}{|c|}{ Attitude category } & \multirow[b]{2}{*}{$\mathbf{X}^{2}$} & \multirow[b]{2}{*}{ P- Value } \\
\hline & Positive attitude & Uncertain & & \\
\hline & No & No & \multirow[t]{4}{*}{12.567} & \multirow{4}{*}{$\begin{array}{c}\mathbf{0 . 0 0 0} \\
(\leq \mathbf{0 . 0 0 1 )} \\
\text { Highly } \\
\text { significant }\end{array}$} \\
\hline Satisfactory & 20 & 2 & & \\
\hline Average & 22 & 3 & & \\
\hline Unsatisfactory & 10 & 10 & & \\
\hline
\end{tabular}




\section{References}

1. World Health Organization. Health care-associated infections. 2015. Available at: https://www.google.com.eg/url?sa=t\&rc $\mathrm{t}=\mathrm{j} \& \mathrm{q}=\&$ esrc $=\mathrm{s} \&$ source $=\mathrm{web} \& \mathrm{~cd}=1 \& \mathrm{c}$ $\underline{\mathrm{ad}}=\mathrm{rja} \& u a c t=8 \& \mathrm{ved}=0 \mathrm{ahUKEwi} p \mathrm{pNT}$ 5Y3TAhUM7RQKHZIBDe8QFggfM AA\&url=http\%3A\%2F\%2Fwww.who.i nt\%2Fgpsc\%2Fcountry work\%2Fgpsc _ccisc_fact_sheet_en.pdf\&usg=AFQjC NHhwYAOop1OO35TVdjh3vK4ekrsV A. (Retrieved on: 21 March 2017).

2. Burnett KP, Erickson D, Hunt A, Beaulieu L, Bobo P, Shute, P. Clinical: strategies to prevent urinary tract infection from urinary catheter insertion in the Emergency Department. Journal of Emergency Nursing 2010; 36546550. doi:10.1016/j.jen.2009.11.002.

3. Iran J, Sci M. Nosocomial infections: The definition criteria. PMC 2012; 37(2): 72-73. [Online].

4. Kim UL, Nowosielski L, Kallini R, Aala A, Gottdiener A. Nurse driven urinary catheter removal- awareness and attitudes survey. Journal of Hospital Medicine 2015; 10:12.

5. Chenoweth C, Saint S. Preventing catheter-associated urinary tract infections in the intensive care unit. Journal of Critical Care Clinics 2013; 29(1): 19 - 32.

6. Hnelhd. Adult urethral catheterization for acute care settings. 2015. Available at:

https://www.health.nsw.gov.au/policies/
7. Mody L, Saint S, Galeck A, Chen Sh, Kren SL. Knowledge of evidence based urinary catheter care practice recommendations among healthcare workers in nursing homes. Am Geriatric Soc 2011; 58:6.

8. El-Sayed ZM, Gomaa A. Abdel-Aziz M. Nurses' knowledge and practice for prevention of infection in burn unit at a University hospital: Suggested Nursing Guidelines. IOSR-JNHS 2015; 4(4): $62-$ 69. Available at: http://www.iosrjournals.org/iosrjnhs/papers/vol4-issue4/Version1/H04416269.pdf.

9. Lo E, Nicolle LE, Coffin SE, Gould C, Maragakis L, Meddings J, Pegues DA, Pettis MA, Saint S, Yokoes D. Strategies to prevent catheter associated urinary tract infection in acute care. Infection Control and Hospital Epidemiology 2014; 35:5.

10. Oman KS, Makic MB, Fink R, Schraeder N, Hulett $\mathrm{T}$, Keech $\mathrm{T}$, Wald $\mathrm{H}$. Nurse-directed interventions to reduce catheter-associated urinary tract infections. American Journal of Infection Control 2011; 40:6.

11. Miller S. Indwelling catheter care. 2015. Available at: https://medlineplus.gov/ency/patientinst ructions/000140.htm.

12. Drekonja DM, Kuskowski MA, Johnson JR. Foley catheter practices and knowledge among Minnesota physicians. American Journal of Infection Control 2010; 3(8): 694-700. doi:10.1016/j.ajic. 03.011. 
13. Jain M, Dogra V, Mishra B, Thakur A, Loomba S. Knowledge and attitude of doctors and nurses regarding indications for catheterization and prevention of catheter associated urinary tract infection in a tertiary care hospital. Indian Journal of Critical Care Medicine 2015; 19(2): 76-81.

14. Sessa A, Giuseppe GD, Albano L, Angelillo I. An investigation of nurses' knowledge, attitude, and practice regarding disinfection procedures in Italy. BMC 2010; 11:148.
15. Galiczewski J, Shurpin K. An intervention to improve the catheter associated urinary tract infection rate in a medical intensive care unit: Direct observation of catheter insertion procedure', Intensive \& Critical Care Nursing 2017; 40:26-34. Science Direct, EBSCO host. (Retrieved on: 11 September 2017). 